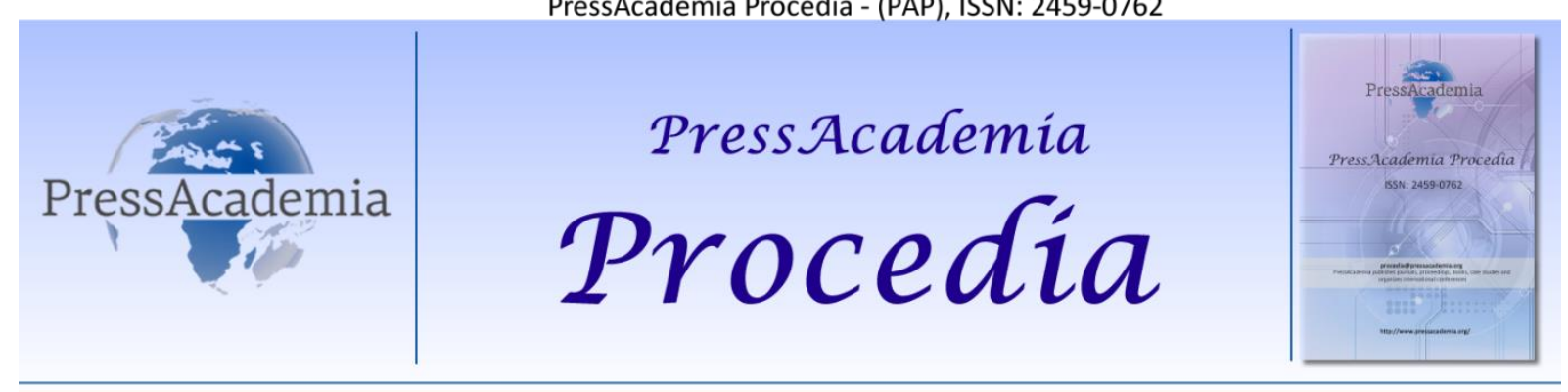

2nd World Conference on Technology, Innovation and Entrepreneurship

May 12-14, 2017, Istanbul, Turkey. Edited by Sefer Şener

\title{
BLACKOUT AND BLACKSTART ON POWER SYSTEMS
}

\section{DOI: 10.17261/Pressacademia.2017.589 \\ PAP-WCTIE-V.5-2017(27)-p.190-197}

\author{
Cihan Ayhanci ${ }^{1}$, Beyazit Yasar Yoldas ${ }^{2}$, Bedri Kekezoglu ${ }^{3}$ \\ ${ }^{1}$ Yildiz Technical University, Department of Electrical Engineering, Istanbul, TURKEY, cihanayhanci20@gmail.com \\ ${ }^{2}$ Turkish Electricity Transmission Company, Istanbul, TURKEY, yasarbeyaz@gmail.com \\ ${ }^{3}$ Yildiz Technical University, Department of Electrical Engineering, Istanbul, TURKEY, bkekez@yildiz.edu.tr
}

\begin{abstract}
Power systems are complex structures that energy production, transmission and consumption units. There are various reasons for energy interruptions on these systems. Power outage on the power system can lead to partial or complete loss of the network. Energy interruptions in large regions cause significant economic losses and precautions must be taken in this regard. In this study, Blackout situations in power systems were analyzed. Within the scope of the study, important Blackout situations encountered around the world have been examined. Blackout causes are listed and interpreted in power systems in the light of experienced events. Precautions have been put forward in order to avoid blackout situations. In addition, the effects of blackstart-equipped power plants on the recovery of the network have been examined.
\end{abstract}

Keywords: Power system analysis, blackout, blackstart, power system restoration, power grid

\section{INTRODUCTION}

One of the basic needs of human beings is electricity energy at nowadays. Everything from our life is utilized by electricity energy, from health to transportation, from fun to traffic (Pakize C., 2011). As a result, social and economic influences are inevitable in a interruption situation.

On energy systems that enable energy to reach consumers without problems in normal operating conditions, energy interruptions can occur due to disturbing currents (Zeng B., 2015). Especially when the power system, which is defined as power grid collapse, is partially or completely out of order, it is the most negative situation for power system operators. In the literature, blackout situations that can occur on power systems have been examined in detail. In one part of the studies done, the blakouts that have taken place on the world and have been realized so far have been examined and their causes and results have been questioned (Olga P, 2016), (Ji-Jen W, 2007), (ENTSOE, 2015), (UCTE, 2004), (Hordeski M., 2005), (Hines P., 2009). Restoration of the power grid after blackout occurred on the system is considered as an important issue (Kurup S., 2015), (En L., 2015), (Ketabi A., 2001), (Ancona J.J., 1995). The use of different energy sources for network restoration and the use of the micro,grid concept to eliminate blackouts has also been a major research topic (Gencheva R., 2015), (Castillo A., 2013), (Clean Technica, 2016).

In this study, blackout situations which can occur on power systems are defined, causes and results are examined. Some of the major blackouts on the world and in Turkey are presented. The use of production systems with blackstart for the restoration of the network has been investigated. The qualities to be found in the systems with blackstart feature are listed and their advantages are presented.

The rest of the work continues as follows. In section 2, informations about electricity networks and structures were made and power grid collapses were examined. Section 3 discusses the work done to restore power grid and the blackstart feature. Work with Section 4 has been terminated. 


\section{VOLTAGE COLLAPSE ON ENERGY SYSTEMS}

Energy systems are the sum of equipment operated in coordination with each other. The goal of the energy system to operate smoothly is to ensure that energy is delivered to the consumer in an uninterrupted form. However, in some cases, all or partial of the system may be out of order. Voltage collapse also known as out of order of the system can occur under conditions of faults, overload, imbalance, inadequate reactive power support, and etc. (Ji-Jen W., 2007).

\subsection{Electric Power Systems}

Electric power systems are a integrated system that is built to deliver generated electricity to consumers. Basically, the power systems examined in three parts namely production systems, transmission systems and distribution systems, are shown in Figure 1 with their most basic form. Electric energy obtained by using different sources on a power system is transmitted to consumption points with high voltage lines as high as possible and delivered to consumers at the required voltage level.

Figure 1. Structure of the Electric Power Grid (MBizon, 2010)

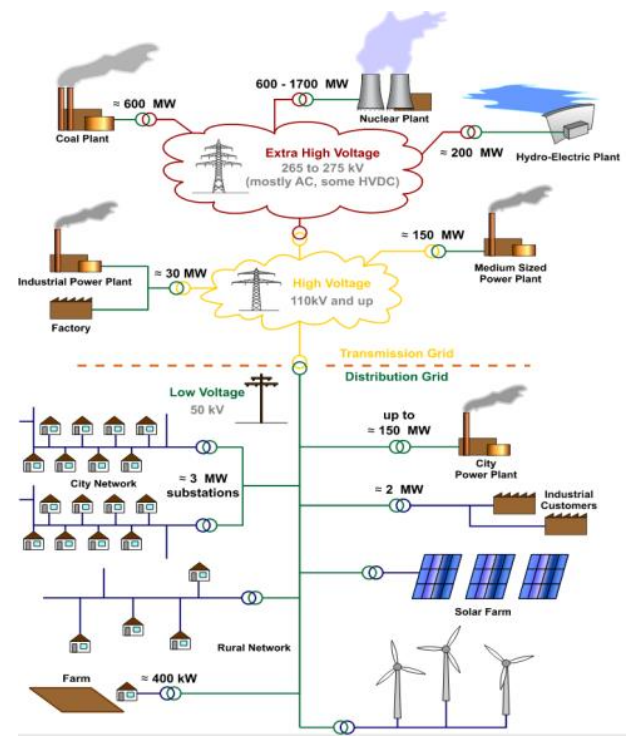

The continuous delivery of electricity to the user is directly related to the reliability of the system. Reliability can be improved by essential maintenance on the power systems, operating the system on optimal conditions, and expanding or renewing the system when the system is insufficient. On the other hand, partial out of service conditions may occur on the system, which in turn brings significant economic losses.

\subsection{Blackout of Electric Power Grid}

Electric power grid serves as a bridge between energy production plants and consumers. Energy supply-demand balance problems can ocur in time. These problems can cause the voltage and frequency of the power grid to increase or decrease. As a result of these occuring distortions, the power system is causing the power generation plants to be out of order through the protection relays. As a result, the synchronization in the power grid is starting to finish and the system is partially or completely collapsed. In other words, if the nominal frequency and voltage values of the system can not be nominal, the blackout of the system is inevitable (Zeng B., 2014).

Firstly, the preconditioning of the system must be investigated before the destructive effect, and the event that initiates the collapse should be investigated. The cascade events that come along with this event are the trigger of the collapse. If the system can not be intervened, the entire power grid can be lost. The first thing to do in the last phase of the collapse of the power grid is to initiate the restoration process (Yvon B.,2013). Phases of power grid collapse are shown in Figure 2. 
Figure 2: The Phase of the Collapse of the Power Grid (Yvon B., 2013)

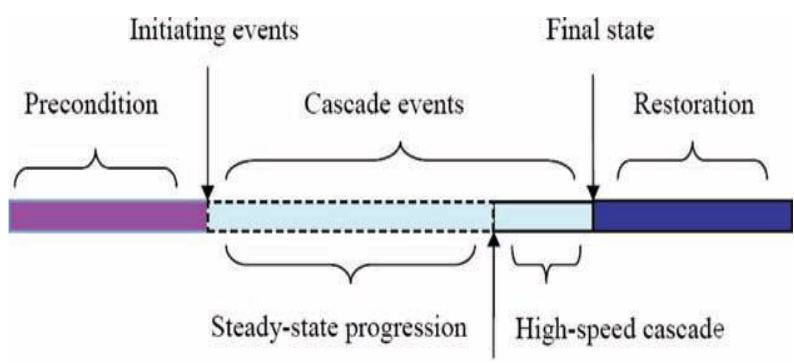

Triggering events

\subsubsection{General Reasons for Power Grid Collapses}

The collapses that occur in power systems arise due to five main factors in terms of system engineering (Yvon B., 2013). These are;

- Voltage loss

- Frequency loss

- Phase angle imbalance

- Production - consumption imbalance

- Synchronization loss

can be sorted as. The factors listed above do not occur under normal operating conditions. On the other hand, it can happen to collapse on the power grid with the effect of disruptive events that can occur inside or outside the system. The main disruptive effects that may cause blackouts on the system are listed below (Pakize C., 2011) :

- Overloading of the equipment used on the system

- Meteorological conditions

- Power system faults

- Fire, flood, earthquake etc. natural events

- Operation mistakes

- Wrong protection

- Sabotage, cyber attack, etc. situations

- Insufficient knowledge and experience

\subsubsection{General Results of Power Grid Collapses}

In the case of loss of energy in power systems or inability to reach consumers, both social and economic effects arise. In social terms, the problems that consumers may encounter are listed below:

- Health, education, transportation etc. services interruption

- Traffic problems beginng

- $\quad$ Lighting problems and related problems

- Communication network weakening

- Problems related to the inability to use electrical household equipment

In addition to all these, there are significant economic impacts due to the halt of production units, the failure of financial institutions, and the loss of industrial facilities.

\subsubsection{Major Blackouts Occured on The World and Turkey}

Blackout events can occur on power systems due to different reasons. Examples of headlines from the main blackout event on Earth are shown in Table 1 (Zeng B., 2015), (Yvon B., 2013), (ENTSOE, 2015), (UCTE, 2004), (UCTE, 2006).

Considering the interruptions that are taking place on the world, it is seen that 670 million subscribers in India in 2012 have been left without energy. In the case of Blackout in the Pakistani energy system, there are 160 million subscribers. In general, the duration of interruption varies between 5 and 10 hours. However, after the Blackout in Canada in 2003, the system recovered 192 hours of complete recovery (Olga P. V., 2016). 
When the causes of the blackout events shown in Table 1 are examined, it is seen that there are interruptions due to overloading and heating problems especially in eastern countries. Besides these, operator errors, inadequate protection system, meteorological conditions and failures arise as other causes of blackout.

Table 2 presents the main blackout events and details seen in Turkey from 1999 to the present day. Table 2 shows that blackout events are caused by disasters, meteorological events and system operation problems. When the details of the Blackout incidents were examined, it was seen that in 1999 and 2016, the direct transmission system was interrupted as a result of the damage directly. The energy transmission lines were damaged due to the earthquake in 1999, and in 2016, demolition occurred in the poles due to excessive ice load (enerji.gov.tr, 2016). The beginning of the event in 2015 is emerging as a operation problem. During the event, production is concentrated in one region and consumption in another region. However, the energy system has been divided into two, the frequency drop in one part and the collapse in the other part due to the frequency increase (ENTSOE, 2015).

Table 1: Major Blackout Incidents on the World

\begin{tabular}{|c|c|c|c|c|c|}
\hline & Date & Country & & Date & Country \\
\hline 1 & 11.9.65 & Northeast of US & 24 & 12.1.98 & San Francisco and California, US \\
\hline 2 & 5.1 .77 & Miami, US & 25 & 7.1 .99 & New York City, US \\
\hline 3 & 7.1 .77 & New York City, US & 26 & 3.11 .99 & Brazilian power system \\
\hline 4 & 12.19.78 & France & 27 & 1.2 .01 & India \\
\hline 5 & 1.1 .81 & Idaho, Utah and Wyoming, US & 28 & 1.12 .03 & Croatia and Bosnia Herzegovina \\
\hline 6 & 3.1 .82 & Oregon, United States & 29 & 3.31 .03 & Iran \\
\hline 7 & 12.27 .83 & Sweden & 30 & 8.14 .03 & Northeast of US and Canada \\
\hline 8 & 7.23 .87 & Japan & 31 & 8.28 .03 & South London \\
\hline 9 & 1.12 .87 & Western France & 32 & 9.5 .03 & The West Midlands, UK \\
\hline 10 & 3.13 .89 & Qubec, Canada & 33 & 9.23 .03 & Eastern Denmark and Sweden \\
\hline 11 & 8.24 .94 & Italy & 34 & 9.28 .03 & Italian power system \\
\hline 12 & 12.14 .94 & Arizona and Washington, US & 35 & 11.7 .03 & Most of Chile \\
\hline 13 & 1.17 .95 & Japan & 36 & 7.12 .04 & The Athens and Southern Greece \\
\hline 14 & 6.8 .95 & Israel & 37 & 3.14 .05 & Queensland, South Australia \\
\hline 15 & 3.12 .96 & Florida, US & 38 & 5.25 .05 & Moscow, Russia \\
\hline 16 & 4.16 .96 & Southwestern of US & 39 & 9.24 .06 & Pakistan \\
\hline 17 & 7.2 .96 & 14 states in the US & 40 & 11.4 .06 & European power system \\
\hline 18 & 8.7 .96 & Big Rivers Electric Corporation, US & 41 & 4.26 .07 & Colombia \\
\hline 19 & 8.10 .96 & California Pacific Northwest, US & 42 & 2.26 .08 & Florida, US \\
\hline 20 & 8.26 .96 & New York City, US & 43 & 2.4 .11 & Brazilian power system \\
\hline 21 & 9.21 .96 & Allegheny Power System, US & 44 & 9.8 .11 & Arizona and Baja California, US \\
\hline 22 & 10.30 .96 & New York City, US & 45 & 7.31 .12 & India \\
\hline 23 & 1.1 .98 & Canada, New York, New England & & & \\
\hline
\end{tabular}

Each blackout event on the Turkish power system has been examined in detail and future projections have been established depending on the reasons. In this context, additional supply scenarios were developed, load and reserve power management were updated, necessary renewals were made in the energy system. 
Table 2: Main Blackout Incidents in Turkey

\begin{tabular}{|c|c|c|c|c|}
\hline Date & Initiating Point & Reason & Restoration Time & Result \\
\hline $\begin{array}{l}\text { August 17, } 1999 \\
(03: 02)\end{array}$ & Marmara Region & $\begin{array}{l}\text { Natural disaster } \\
\text { (Earthquake) }\end{array}$ & $\begin{array}{l}\text { The full restoration with } \\
\text { regional restoration } \\
\text { continued until the evening } \\
\text { of August 18th. }\end{array}$ & $\begin{array}{l}62 \text { milyon kişi } \\
\text { elektriksiz kalmıştır. }\end{array}$ \\
\hline $\begin{array}{l}\text { January 14, } 2012 \\
(13: 43)\end{array}$ & $\begin{array}{l}\text { Marmara Region } \\
\text { (Bursa) }\end{array}$ & $\begin{array}{l}\text { Bursa Natural Gas } \\
\text { Combined Cycle } \\
\text { Power Plant's fall } \\
\text { in natural gas } \\
\text { pipeline due to } \\
\text { cold weather }\end{array}$ & $\begin{array}{l}\text { From } 14: 15 \text { hours, electricity } \\
\text { was supplied to Edirne, } \\
\text { Tekirdağ and Kırklareli in } \\
\text { Trakya region. As of } 16: 30 \\
\text { hours, } 80 \% \text { of the } \\
\text { interruption was eliminated } \\
\text { and } 90 \% \text { of the interruption } \\
\text { was eliminated by 19:00 } \\
\text { hours. At 19:15 the operation } \\
\text { of the system returned to } \\
\text { normal operation condition. }\end{array}$ & $\begin{array}{l}\text { Istanbul, Sakarya, } \\
\text { Kocaeli, Tekirdağ, } \\
\text { Kırklareli and } \\
\text { Edirne, more than } \\
20 \text { million people } \\
\text { living in electricity } \\
\text { without electricity. }\end{array}$ \\
\hline $\begin{array}{l}\text { March 31, } 2015 \\
(09: 36)\end{array}$ & $\begin{array}{l}\text { Osmanca - Kurşunlu } \\
\text { energy transmission } \\
\text { lines }\end{array}$ & $\begin{array}{l}\text { Out-of-service } \\
\text { Osmanca,Kurşunlu } \\
\text { energy } \\
\text { transmission lines } \\
\text { carrying } 1127 \mathrm{MW} \\
\text { / } 1237 \mathrm{MVA} \\
\text { because of } \\
\text { overload }\end{array}$ & $\begin{array}{l}\text { As of } 11: 30 \text { am, the Black Sea } \\
\text { and the Eastern Anatolia } \\
\text { Region were synchronized. } \\
\text { At } 16: 12 \text {, the entire system } \\
\text { was restored. }\end{array}$ & $\begin{array}{l}\text { The entire power } \\
\text { grid is left without } \\
\text { energy. }\end{array}$ \\
\hline $\begin{array}{l}\text { December 29, } \\
2016 \\
(14: 20)\end{array}$ & Istanbul & $\begin{array}{l}\text { Seven different } \\
\text { energy } \\
\text { transmission lines } \\
\text { feeding Istanbul } \\
\text { have been } \\
\text { affected by ice } \\
\text { loads and storms }\end{array}$ & $\begin{array}{l}\text { At } 21: 50 \text {, electricity could be } \\
\text { supplied to the whole of } \\
\text { Istanbul }\end{array}$ & $\begin{array}{l}\text { Iron and steel } \\
\text { factories and } \\
\text { cement factories } \\
\text { have not provided } \\
\text { electricity to the } \\
\text { organized industrial } \\
\text { zones and the } \\
\text { demand has been } \\
\text { minimized with } \\
\text { partial interruptions } \\
\text { in the districts. }\end{array}$ \\
\hline
\end{tabular}

\subsubsection{Solution Suggestions for the Prevention of Power Grid Blackouts}

Electricity that is uninterrupted and reliable is so important for consumers. It is imperative to take some precautions not to cause any interruption in the power system. The following measures can be taken to prevent possible collapses in the system:

- Strategies for load management and risk factors should be identified

- Operators must be trained and informed

- The equipment used on the system must be regularly checked

- System should be developed depending on increasing supply and demand

- Necessary precautions should be taken for extreme weather conditions

- Security measures should be taken against sabotages and cyber attacks that may occur in the system.

\section{RESTORATION OF ELECTRIC POWER GRID}

In some cases, the operating conditions of the power system may be broke down. This distortion can cause the power system to collapse or break down. Once such disturbances have occurred, the power should be returned to normal operating conditions as soon as possible (Sreeram R. K., 2015). Hence, it is imperative that the network restoration program of each transmission system operating institution (NERC, 2015). Evaluation of restoration process consists of preparation of subsystems and establishment of target systems. The most important issue in the restoration process is that the evaluation is done carefully and the correct decisions are taken. A delay or wrong decision at the time of the determination causes very serious economic loss in the system. 
The operating conditions in the restoration process differ from the work performed under normal operating conditions. There are some technical issues to consider during restoration conditions. These are the protection of the voltage and frequency values in the system, reactive power control, production and load balancing, energizing the units that need to be energized first, communication and coordination of production operators and operation operators that control the system are required. Another important issue in the restoration process is the creation of controlled islands around the units with blackstart features. With the aid of these islands, the system must be energized step by step and controlled to feed the loads.

It is a very important issue to reduce the recovery period to a minimum during the restoration of the electricity grid. Load distribution centers, transformer centers and operators in power plants should be in very good coordination during the restoration.

As a result of the partial collapse of the electricity network, the production units that have been disabled are energized by utilizing the neighboring systems. However, as a result of the complete system collapse, the system will be energized with blackstart-enabled power generation units.

\subsection{Introduce of the Blackstart Feature of Power Plants}

Blackstart is a feature that allows a production unit or station to switch from a blackout condition to an operating state that provides electrical energy without the help of an electrical grid (Wikipedia, 2014). In normal operating conditions, the electricity used in the power plant is supplied by the production units in the power plant. If all the main production units of the power plant are off, the electricity required by the plant is provided by the energy transmission lines connected to the transmission line of the power plant. If the power grid is blackout completely, the electricity grid is also de-energized. A power generation unit with a blackstart feature is required to return the electrical grid to normal conditions. Some blackstart generators are available to provide blackstart for power plant (Few MW capacities). These generators are used to start large power units. This process enables the entire plant to be energized and energize to the power grid (Agrawal V., 2010).

Nuclear and thermal power plant units must have a ratio of $7 \%$ to $8 \%$ of their energy production capacity to energize units with blackstart capability. Power capacity of hydroelectric power plants should be between $0.5 \%$ and $1 \%$ while the energy production capacity should be between $1.5 \%$ and $2 \%$ on natural gas power plants (The National Grid, 2001).

\subsection{Energy Production Units Used to Provide Black Start}

Generally, hydroelectric power plants are designated as blackstart sources for energizing grid connections because of the hydroelectric power plant needs very little energy to start. Therefore it is most common to use as a blackstart source (Wikipedia, 2014).

Providing blackstart capacity is not economical to create a large standby capacity in fossil fueled power plants because the equipment has a high internal energy requirement. However, generator sets with the blackstart feature are produced nowadays. Together with the hydroelectric units, diesel generator sets, gas turbine generator sets and gas turbines of large dimensions can be used as a blackstart source (The National Grid, 2001).

In February 2016, a Berlin-based company explained that a battery park with a capacity of 5 MW would be integrated with renewable energy sources and used as a blackstart source. It is announced that the project will last three year (Rob Compton, 2016).

\subsection{System Energization with Blackstart Featured Power Plants}

Blackouts in energy system are rare, but sometimes they can occur. As a result of the blackout of the energy system, the power plants are completely without energy. In this case, generators with the BlackStart feature should be fed primarily with external support units so that the system returns to the normal conditions again. Then the other units of the power plant are energized. Next, out of ordered energy transmission lines in the energized state are also energized. Then the base load plants are energized. Then, other power plants should be stepped in. Then, other power plants should take part step by step on power grid. 


\section{Figure 3: Energizing the Power Grid with the Blackstart Feature}
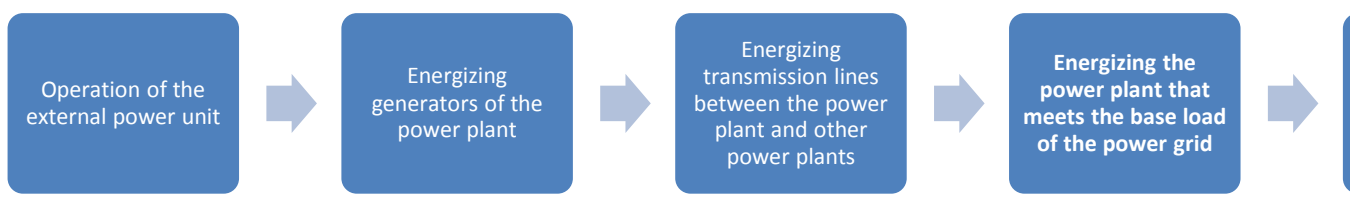

The other power generating plants are powered down and the loads are fed in a controlled manner

\section{CONCLUSION}

Electric energy is utilized at every point of our daily life. As a result, interruptions that may occur on the power grid lead to significant loss. In this respect, blackouts which cause the network to be partially or completely out of service, need to be analyzed in detail.

In this study, the blackout situations that can occur on the electric networks have been examined. The important blackouts encountered on the world and Turkey have been taken into consideration and their causes and results have been analyzed. Measures to be taken to avoid blackout situations have been put forward. In addition to this, the effects of the blackstart stations on the power grid on the recovery of the power grid have been examined.

Considering this study, it has been observed that the use of different energy sources on the power grid both reduces blackout risk and contributes to power grid restoration by blackstart feature.

\section{REFERENCES}

Pakize C., 2011, "Examination of the Blackouts Occured in Interconnected Networks", Graduate Theses, Marmara University, İstanbul.

Zeng B., Ouyang S., Zhang J., Shi H., Wu G., Zeng M., February 2015, "An analysis of previous blackouts in the world: Lessons for China's power industry", Renewable and Sustainable Energy Reviews, Volume 42, Pages 1151-1163.

Olga P. V., Francisco S., September 2016, "Analysis of major blackouts from 2003 to 2015: Classification of incidents and review of main causes", The Electricity Journal, Volume 29, Issue 7, Pages 42-49.

Ji-Jen W., Ching-Tzong S., Chi-Shuan L., Chung-Liang C., October 2007, "Study on the 729 blackout in the Taiwan power system", International Journal of Electrical Power \& Energy Systems, Volume 29, Issue 8, , Pages 589-599

TEIAŞ, ENTSOE Project Group Turkey, September 2015 “Report on Blackout in Turkey on 31st March 2015”

UCTE, April 2004, "Final Report of the Investigation Committee on the 28 September 2003 Blackout in Italy"

UCTE, 2006, “Final Report System Disturbance on 4 November 2006 in Europe"

Yvon B., Mircea E., Nikolai V., 2013, “Major grid blackouts: analysis, classification, and prevention”, IEEE Press, Part 3, Page 813-887 New Jersey.

Alberto B., Carlo A. N., Mario P., 2013, "Restoratıon Processes After Blackouts”, IEEE Press, Part 3, Page 888-923 New Jersey.

Jerry C. W., 2007, "AC Power Systems Handbook", Third Edition, CRC Press, Page 330-341, California.

Hordeski M., 2005, Emergency and Backup Power Sources: Preparing for Blackouts and Brownouts, The Fairmont Press, Inc., United States of America.

Gencheva R., Stefanova A., Groudev P., 2015, "Investigation of station blackout scenario in VVER440/v230 withRELAP5 computer code" , Elsevier, Vol. 295, pp. 441-456.

Hines P., Apt J., Talukdar S., 2009, "Large blackouts in North America: Historical trends and policy implications", Elsevier, Vol. 37, pp. 5249-5259.

Welfonder E., Kurth M., 2007, " Limitation control procedures, required for power plants and power systems Possibility for reducing future blackouts", Elsevier, Vol. 31, pp. 93-104.

Pradhan P., Deki T., Wangmo P., Dorji D., Phuntsho D. and. Dorji C., 2015, "Simulation and Optimization of Blackstart Restoration Plan in Bhutan using DIgSILENT", Proceedings of 2015 RAECS UIET Panjab University Chandigarh 21-22nd December 2015.

Castillo A., 2013, "Microgrid Provision of Blackstart in Disaster Recovery for Power System Restoration", IEEE Smart grid Comm 2013Smart Grid Services and Management Models.

Kurup S., Ashok S., 2015, " Grid Restoration Planning After a Total Blackout", 2015 International Conference on Control, Communication \& Computing India (ICCC) | 19-21 November 2015 | Trivandrum. 
Wang H., Lin Z, Wen F., Ledwich G., Xue Y., Zhou Y., Huang Y., 2014, " Black-start decision-making with interval representations of uncertainfactors", Elsevier, Vol. 79, pp. 34-41.

"Black Start Restoration Procedures Of Southern Region 2013", Southern Regional Load Despatch Centre Power System Operation Corporation Ltd, November 2012, Bangalore.

Agrawal V., Porwal R., Kumar R., Pandey V., 2010, " Mock Blackstart Drills - An Excellent Learning Experience for Power System Operators", CBIP- 5th International Conference on Power System Protection and Automation, 6-9, Dec 2010.

En L., Zhijun Q., Mingbo L., Yunhe H., Ning W., Jinyu W., August 2015, “Increasing Black Start Capacity by Fast Cut Back Function of Thermal Power Plants", International Journal of Smart Grid and Clean Energy.

Ketabi, A., Asmar, H., Ranjbar A.M, Feuillet, R., 2001, "An approach to initiation of optimal units during the restoration of the bulk power system"," 2001, Large Engineering Systems Conference on Power Engineering, Theme: Strengthening after 2001 (Kat. No.01ex490) , Halifax, NS, 2001, s. 190-194

Hafner, Y.J., Duchen, H., Karlsson, M., Ronstrom, L., Abrahamsson, B., 2008, "HVDC with Voltage Source Converters-A Powerful Standby Black Start Facility", IEEE PES T\&D Conference, 21-24 April 2008, Chicago.

The National Grid Company plc, 2001, "An Introduction to Black Start”, Market Development, February 2001

Ancona, J.J., 1995, “A Framework For Power System Restoration Following a Major Power Failure”, IEEE Transactions on Power Systems, Vol. 10, No. 3, August 1995.

Clean Technica, Restoring The Grid After A Blackout - Using Batteries, https://cleantechnica.com/2016/02/02/restoring-the-grid-after-ablackout-using-batteries/, 24 April 2017.

Sun, W., Liu, C.C., Liu, S., 2011, “Black Start Capability Assessment in Power System Restoration”, IEEE, 978-1-.4577-1002-5/11.

Lindenmeyera, D., Dommela, H.W., Adibi M.M., 2001, "Power system restoration- A bibliographical survey", Electrical Power and Energy Systems, 23: 219-227.

Feltes, J.W., Moran, C.G., 2008, “Black Start Studies for System Restoration”, IEEE, NewYork 12305.

Zeng, S., Lin, Z., Wenb, F., Ledwich, G., 2012, "A new approach for power system black-start decision-making with vague set theory", Electrical Power and Energy Systems, 34: 114-120.

Joglekar, J.J., Nerkar, Y.P., 2008, "A different approach in system restoration with special consideration of Islanding schemes", Electrical Power and Energy Systems, 30: 519-524.

Barsali, S., Giglioli R., Poli, D., Sforna M., Salvati R., Zaottini R., 2008, "The restoration of an electric power system: International survey and discussion of possible innovative enhancements for the Italian system", Electric Power Systems Research, 78: $239-247$.

Jiang Y., Chen, S., Liu C.C., Sun W., Luo, X., Liu, S., Bhatt, N., Uppalapati, S., Forcum, D., 2017, “Blackstart capability planning for power system restoration", Electrical Power and Energy Systems, 86: 127-137.

Barsali S., Polia, D., Praticò, A., Salvati, R., Sforna, M., Zaottini, R., 2008, "Restoration islands supplied by gas turbineS", Electric Power Systems Research, 78: 2004-2010.

Kleppingera, D., Broadwatera R., Scirbona C., 2010, “Generic reconfiguration for restoration”, Electric Power Systems Research, 80: 287295.

Yılmaz, O., 2011, "System Restoration and "Black start" Qualification of Technical Units, Technical Criteria, Evaluations and Test Procedures", Tübitak Space Technologies Research Institute-Teiaş-Ekh Tdep, 30 September 2011.

Lopes, J.A.P., Moreira, C.L., Resende, .O., 2005, "MicroGrids Black Start and Islanded Operation", 15th Power Systems Computation Conference, 22-26 August 2005, Liege.

Zhang, G., 2009, “EPRI Power Systems Dynamics Tutorial”, Palo Alto, 1016042.

Sun, W., 2011, "New optimization techniques for power system generation scheduling", Graduate Theses and Dissertations, lowa State University, lowa City, p.1220.

Zhang, X.P., 2015, "Emerging Capability on Power System Modelling: System Security, Resilience and Recovery Modelling", The Instution of Engineering and Technology, 8:1-15.

MBizon, 2010, "Electricity Grid Schematic English", commons.wikimedia.org/wiki/File:Electricity_Grid_Schematic_English.svg.

Wikipedia, 2014, en.wikipedia.org/wiki/Black_start.

Nort American Electric Reliability Corporation(NERC), December 2015, “2015 Long-Term Reliability Assessment”, Atlanta. 